\title{
Go native. Debaty o książce Timothy Snydera
}

\author{
Joanna Tokarska-Bakir
}

Niniejszy blok omówień ostatniej książki Timothy Snydera jest bodaj pierwszym tak obszernym zbiorem jej krytycznych recenzji, jakie ukazują się w Polsce [Snyder 2010; 2011] ${ }^{1}$. Choć patrząc z krajowej perspektywy mogłoby się wydawać, że wszystko w tej sprawie zostało już powiedziane, zawartość najnowszego numeru „Contemporary European History" z 2012 r. (rocznik 21, nr 2) przekonuje², że na świecie dyskusja o książce dopiero się zaczyna. Ponieważ wiele podnoszonych w niej argumentów współbrzmi z tymi, które wysuwają nasi autorzy, przed lekturą ich tekstów warto zapoznać się z szerszą, międzynarodową perspektywą debaty.

Dyskusję w „Contemporary European History” otwiera głos Marka Mazowera, który uważa, że zasadniczym osiągnięciem Snydera jest podważenie poglądu, jakoby miejscem masowych mordów w skali największej w XX w. były obozy zagłady. Okazuje się, że więcej ofiar pociągnęły za sobą inne wypróbowane technologie śmierci: głód i pluton egzekucyjny, co Snyder rozpatruje w kontekście „bliskich związków pomiędzy reżimami Hitlera i Stalina”. Mazower przywołuje zaraz nazwisko Hanny Arendt, która głosiła wspomnianą tezę o obozach jako największych dwudziestowiecznych fabrykach śmierci i dla której, zdaniem Mazowera, akurat te związki pomiędzy reżimami pozostawały niewidoczne. Jako pierwszy zauważył je Ernst Nolte, od którego rozpoczął się Historikerstreit [Historikerstreit 1987; Kailitz (red.) 2008]. Uchwyciwszy zasadę, nie potrafit jej jednak poprawnie wyeksplikować - zbrodnie nazistowskie miały być jakoby wyprzedzeniem bolszewickich, ponadto „apologetyczny" ton jego wystąpień na długie lata wykluczył podobne tezy z kręgu rozważań historycznych. Zbliżone zadanie, podjęte następnie przez Alana Bullocka [Bullock 1993] i Richarda Overy'ego [Overy 2004], podzielić miało los pioniera. Dopiero książka Snydera przełamuje passę, dodając, zdaniem Mazowera, dwa lub trzy nowe wymiary do tego, co określa się tu mianem „bliźniaczego zła”. Podkreśla bowiem interakcję reżimów, skupia się

1 Por. np. recenzje i dyskusje zamieszczone w polskiej prasie tak różnych orientacji, jak np. „Gazeta Wyborcza” [Leszczyński 2010; Kalicki 2011], „Tygodnik Powszechny” [Sienkiewicz 2011]; „Kultura Liberalna” [Holzer, Kuisz, Jasina, Kenney 2011; Skrwawiony teatr 2011] czy „Uważam Rze” [Snyder 2012a]. Wcześniej przekład recenzji Omera Bartova oraz obszerną recenzję Andrzeja Żbikowskiego zamieścił rocznik „Zagłada Żydów. Studia i Materiały” z 2011 r. [Bartov 2011; Żbikowski 2011].

2 Uczestnicy debaty to: Mark Mazower (Columbia University), Dan Diner (Hebrew University/Simon-Dubnow-Institute Leipzig), Thomas Kühne (Clark University) i Jörg Baberowski (Humboldt University). Ich głosy Timothy Snyder komentuje obszernym esejem, kończącym debatę w "Contemporary European History”. 
na problematyce popełnianych przez nie masowych mordów, a także, co metodologicznie najważniejsze, „zawęża wywód do ścisłych granic regionalnych”, w obrębie których reżimy te operowały. Snyderowi przychodzą w sukurs przemiany w angloamerykańskim świecie naukowym, który, według Mazowera, dopiero ostatnio nauczył się „traktować kwestię [powyższych] porównań w sposób profesjonalny i mniej tendencyjny".

Odnosząc się do interakcji między reżimami, Mazower zapisuje na konto Snydera przywrócenie znaczenia historii dyplomacji, marginalizowanej dotychczas w amerykańskiej historiografii na rzecz historii społecznej i kulturowej. Na tle ostatniego zwrotu ku geopolityce podejście Snydera ma także dowodzić swych przewag. Recenzent docenia zainteresowanie Snydera Polską, dzięki któremu odkrywa on tak ważne aspekty epoki, jak lęk ZSRR przed znalezieniem się w okrążeniu, a także przypomina o strefie buforowej, w której współpracowali ze sobą Sowieci i Niemcy. Z książki dowiadujemy się takich rewelacji, jak choćby wymiana korespondencji pomiędzy mocarstwami w sprawie ewentualnej ekspulsji Żydów z terenu Rzeszy na teren ZSRR. Przy wszystkich pochwałach Mazower pozostaje jednak krytyczny w stosunku do szczegółowych rozważań autora, zarzucając im niewystarczającą wnikliwość. „Snyder wspomina, że pamięć o sowieckiej okupacji we wschodniej Polsce i krajach bałtyckich stała się zapłonem przemocy antyżydowskiej w pierwszych tygodniach po wkroczeniu Niemców, ale wzorowany na Leopoldzie von Ranke tryb postępowania [patrz dalej] nie pozwala mu na analizę wpływu jednej okupacji na drugą, takiej choćby, jakiej dostarczyła praca historyzującego socjologa Jana Grossa" [Gross 1988; Chodakiewicz 2004]. Mazower ocenia, że narracja Snydera składa się z rozmaitych znanych elementów, tyle że inaczej ułożonych. Rozpoczyna się w roku 1933 głodem na Ukrainie, przechodzi w opis stalinowskich czystek, „osiąga apogeum w Holokauście, kończy się przymusowymi deportacjami i kampanią antysemicką w drugiej połowie lat czterdziestych”. Tak opisywane „skrwawione ziemie” ustanawiają oś historii Europy pierwszej połowy ubiegłego wieku.

Tym bardziej zaskakujące, zauważa Mazower, że w rezultacie podobnego zabiegu status „skrwawionych ziem” paradoksalnie ulega deprecjacji. Traci charakter „terytorium politycznego", spadając do rangi li tylko geograficznego miejsca rozgrywki dwóch potęg. Ceną uznania za kluczową strefę historii europejskiej staje się jego ubezwłasnowolnienie. Kolejne zarzuty odnoszą się więc do selekcji faktów, wynikającej z przyjętej przez Snydera narracji, np. do braku nawiązań do polityki wewnętrznej niepodległej Polski i krajów bałtyckich, w tym do ich polityki wobec mniejszości. Dalej pojawia się kwestia kolaboracji polskiej, ukraińskiej czy białoruskiej - przez Snydera pominięta. Także „polski antysemityzm jest zbyt lekko potraktowany, brak jest wzmianki o pogromie kieleckim i innych. Można przeceniać znaczenie wschodnioeuropejskiego antysemityzmu [...], nie można go jednak nie doceniać" - pisze Mazower. Kolejny brak w książce dotyczy masowych mordów dokonywanych na sobie nawzajem przez lokalne populacje, w tym krwawych rozliczeń polsko-ukraińskich w czasie wojny i po jej zakończeniu. Fascynacja mordem zorganizowanym, „państwowym”, najwyraźniej nie pozwala dostrzec mordowania codziennego 
i spontanicznego. Trafną obserwację formułuje Mazower odnośnie do sposobu, w jaki Snyder charakteryzuje oba systemy: „dostrzega on czasem podobieństwa, a nawet związki pomiędzy sposobem, jak oba reżimy mordowały swoje ofiary, czy też po prostu - jak pozwalały im umrzeć. Ale na moment przed rozwinięciem tematu porzuca go, powracając do własnej narracji”. „Europejska epoka masowych mordów jest nadmiernie obciążona teorią i przez to niezrozumiała" - tłumaczy ten zabieg Snyder. Zanim posłużymy się teorią, musimy zrozumieć, „co się właściwie stało”. To przywołanie ideału przedteoretycznej, dziewiętnastowiecznej historiografii zdumiewa w dziele amerykańskiego historyka. Kluczową kwestią, aby zrozumieć „jak to było naprawdę”, są przywołane porównania. Dlaczego jednak porównywać tylko Niemcy i ZSRR? Recenzent wyraża wątpliwość, czy słusznie ograniczono tu zarówno comparanda, jak też sam obszar „skrwawionych ziem”, tak by nie objęły np. południowej Europy (ustasze i reżim Antonescu). W końcowej części recenzji Mazower wyraża zawód związany z niespełnioną przez autora obietnicą wyjaśnienia mechanizmów zabijania. Jeden z głównych Snyder kwituje zdaniem: „Z perspektywy czasu umarli stawali się argumentem na rzecz słuszności polityki [reżimu]”. Przemoc miała więc wynikać z frustracji, spowodowanej niemożnością spełnienia się utopii, i służyła temu, aby wzmocnić legitymizację władzy w oczach społeczeństwa. Mazower sądzi, że ani głodu na Ukrainie, ani Holokaustu nie można jednak przypisać powyższej genealogii przemocy. Podobnie nie przekonują go hipotezy przeludnienia jako czynnika, który ją wywołuje.

W konkluzji Mazower nazywa książkę Snydera „rozpamiętywaniem raczej niż wyjaśnianiem" procesu historycznego. Można to przypisać sprzeciwowi Snydera wobec Heglowskiej wizji historii: wbrew Heglowi, cierpienie nie ma żadnego celu; jego jedyną funkcją jest blokowanie przez reżim dostępu do rzeczywistości. Zapomnienie, w jakie spychane są masowe mordy, staje się częścią mechanizmu obronnego, rządzącego procesem zbrodniczej legitymizacji ${ }^{3}$. Stąd wynika podkreślanie przez Snydera etycznej siły pamięci i odpowiedzialności historyka, którego misją jest „uniwersalizowanie tego co poszczególne”, a także występowanie w charakterze rozjemcy pomiędzy zwalczającymi się pamięciami. Ma on pomagać narodom wydostawać się z klatki własnej narracji historycznej.

Nie znamy opinii autora recenzji na temat zadań, jakie Snyder stawia przed historykami. Tekst kończy się serią rzeczowych pytań. Dlaczego książka Snydera zaczyna się w roku 1933, a nie wcześniej? Dlaczego eksponowany jest wyłącznie Stalin, a nie Lenin? Co oznacza twierdzenie, że „agresywne wspólnictwo” [belligerent complicity] reżimów legło u źródeł masowych mordów? „Czemu tak niewiele uwagi przywiązuje się tu do czynnika lokalnego - roli odgrywanej przez Ukraińców, Polaków, Żydów i innych - w wyjaśnianiu przemocy tych lat? I w końcu: co jest stawką w uprzywilejowaniu «skrwawionych ziem» [bloodlands] w stosunku do pogranicza [borderlands], innymi słowy w wykluczaniu strefy rozciągającej się na południe, na wskroś Bałkanów przez Anatolię aż po Bliski Wschód? Czystki etniczne z połowy lat czterdziestych miały miejsce w wielu częściach świata - we

3 Zauważmy na marginesie, że ta hipoteza kwestionuje większość przyjętych teorii legitymizacji jako procesów wyposażonych w społeczną racjonalność i odwołujących się do obiektywnej racjonalności. 
wschodniej Europie, ale także na Bliskim Wschodzie i w południowej Azji. W jaki sposób zakres geograficzny rozpatrywanej przemocy rzutuje na odpowiedzi dotyczące tego, jak owa przemoc rodzi się i zanika?"

Drugi $z$ autorów, Dan Diner, zwraca uwagę na brzmieniowe podobieństwo tytułowych bloodlands z borderlands, w których słyszy polskie słowo „Kresy”. Historyk dopatruje się w nich ilustracji polonocentryzmu Snydera. Podobnie rozumie przekodowanie znaczeń roku 1933, w tradycyjnej historiografii kojarzonego z dojściem Hitlera do władzy, teraz natomiast złączonego ze sztucznym głodem na Ukrainie. Diner uważa, że podobna dyslokacja koordynat czasowo-przestrzennych pozwala Snyderowi tak operować środkiem ciężkości, by znalazł się on w zasięgu „tradycyjnej polskiej narracji historycznej - dobrze ugruntowanej opowieści o tragedii narodu, uwięzionego pomiędzy potęgami Wschodu i Zachodu". Pozwala także na rozszerzenie dziewiętnastowiecznej polskiej narracji niepodległościowej o figurę starcia dwóch totalitaryzmów, w które przeobrazili się tradycyjni wrogowie Polski. Diner wskazuje alternatywne, pozornie bardziej pasujące do koncepcji Snydera opcje chronologiczne: rozpoczęcie opowieści od wojny polsko-bolszewickiej czy od wybuchu pierwszej wojny światowej - z ważnych zapewne przyczyn odrzucone. Podobnie pominięte zostały, jego zdaniem, inne elementy obrazu, takie jak „charakterystyczna dla Kresów tkanka konfliktów i przemocy”, zbudowana z relacji pomiędzy polską mniejszością ziemiańską a ukraińskim i białoruskim chłopstwem. W książce Snydera nie ma też ani jednej wzmianki o okrucieństwach armii carskiej (dodajmy: również Armii Czerwonej) przeciwko ludności kresowej, głównie Żydom, a w roku 1916 przeciwko muzułmańskim nomadom Federacji Kirgisko-Kazachskiej w Azji Środkowej.

Zdaniem Dinera, wszystkie te zabiegi - wymienia ich zresztą znacznie więcej - mają na celu podważenie wyjątkowego statusu Holokaustu. Diner optuje za wyrażaną przez Snydera intencją umieszczenia zjawiska w szerszym niż dotąd kontekście wojennego rozlewu krwi, uważa jednak, że książka nie spełnia tego zadania. Intencje Snydera wydają mu się „wysoce ambiwalentne”. „Z jednej strony, jego podejście można opisać jako wyraźnie skoncentrowane na Zagładzie: chodzi mu o przedstawienie owej szczególnej wojny, jaką wypowiedziano Żydom, nie zważając na rysującą się już na horyzoncie niemiecką klęskę militarną na Wschodzie. Gdyby Związek Radziecki został pokonany, Żydzi zostaliby przesunięci - jak formułuje to aluzyjnie - na «Wschód». ZSRR jednak nie uległ, w związku z czym Żydzi stali się celem radykalnego i całkowitego unicestwienia. Z drugiej strony, Snyder w sposób oczywisty zamierza podważyć pogląd, że Holokaust oznaczał przede wszystkim prowadzące do eksterminacji, «przemysłowe» zabijanie, szczególnie w Auschwitz, a także zasugerować, że był on raczej masakrą i śmiercią na masową skalę [poza obozami śmierci]. Przypomina o tym kilkakrotnie, podkreślając, że znacznie więcej Żydów zabito w trakcie rozstrzeliwań (tak zwany «Holokaust od kul») niż za pomocą gazu”. 
W wykazaniu nietrafności koncepcji „skrwawionych ziem” kluczową rolę - według Dinera - odgrywa właśnie problematyka Auschwitz. Po pierwsze, ze względu na historyczną topografię, która podważa wyznaczoną przez Snydera przestrzeń destrukcji, bowiem do Auschwitz wysyłano także Żydów greckich, węgierskich, francuskich i holenderskich, których to krajów w książce się nie uwzględnia. Po drugie zaś dlatego, że owa alternatywna topografia „wyposażona jest w zupełnie inną historyczną epistemologię - epistemologię, która może rzutować zarówno na nasze rozumienie masowych mordów w kontekście wojny, jak i poza nim, szczególnie gdy mowa o Związku Radzieckim roku 1930". O ile bowiem Snyder, kierowany intencją niewątpliwie etyczną, nie rozróżnia ofiar ludobójczej, motywowanej politycznie przemocy, taka różnica niezaprzeczalnie istnieje. „Pola śmierci” bynajmniej nie są tak homogeniczne, jak się to w książce Snydera przedstawia. Wskazuje na to kojarzona z Auschwitz, rozciągnięta daleko na zachód i południe „topografia unicestwienia”. Zginąć mieli wszyscy Żydzi, w tym także garstka dosłownie pojedynczych Żydów norweskich, czy tych wyłuskanych z Rodos, których los do końca nie przestawał być ważny. Może to się wydawać mało istotne w porównaniu z hekatombą, jaka miała miejsce na „skrwawionych ziemiach”, niemniej jednak znaczenie epistemiczne i jakościowe tych śmierci musi zostać wzięte pod uwagę. Nie chodzi o porównywanie tragedii, z których każda, szczególnie z punktu widzenia ofiar mordu jest absolutem. Chodzi o kwestię prawidłowego osądu historycznego, a także pytań, jakie wynikają (lub nie) ze stworzonej przez autora narracji.

\section{III}

Thomas Kühne, który zatytułował swoją recenzję Wielcy ludzie i wielkie liczby: redukowanie teorii w refleksji nad historia masowych mordów, rozpoczyna w miejscu, w którym Dan Diner zakończył: „Nauka to nie tylko poszukiwanie nowych sposobów poznania, ale także walka o polityczny wpływ i udział w rynku - dostęp do funduszy publicznych i prywatnych, do stanowisk akademickich, indeksu cytowań i obecności w mediach". Środek ciężkości współczesnej historii Europy stanowił do tej pory Zachód występujący jako prekursor nowoczesności. „[Wszyscy byli zgodni, że] Związek Radziecki na miano centrum żadną miarą nie zasłużyt”. Snyder dokonuje zmiany w tym obrazie, wprowadzając kategorię bloodlands, ziem pomiędzy Niemcami i Rosją, terytorium, które w wieku XX ucierpiało najbardziej. Cierpienie Wschodu jest wymierne - autor sugestywnie operuje tu liczbami. Kühne rozpoczyna od przypomnienia, że słuszny skądinąd pomysł decentralizacji, a raczej przesunięcia na wschód, europejskiego teatru prezentacji (w sensie historycznym) przeszłości bynajmniej nie jest nowy. Od końca zimnej wojny upominali się o to historycy, usiłujący rozszerzyć pojęcie Europy Środkowej tak, by objęło też inne kraje regionu. Ich wysiłkom przyświecała intencja przeciwdziałania jego marginalizacji w głównym nurcie historiografii. Jednym z najważniejszych głosów w tym zakresie był artykuł Omera Bartova z roku 2008, w którym protestował on przeciwko hegemonii 
historii Trzeciej Rzeszy w dziedzinie badań nad Holokaustem [Bartov 2008] ${ }^{4}$. Zbyt długo, dowodził, badacze ograniczali się do badania źródeł niemieckich. Losy i przeżycia ofiar terroru nazistowskiego (żydowskich i nieżydowskich), które mówiły językami innymi niż niemiecki, nie wzbudzały niczyjego zainteresowania. Wciąż ma to istotne implikacje dla polityki pamięci w całej Europie, tym bardziej, że także dekady komunizmu przyczyniły się do wymazania pamięci o ofiarach, które były Żydami.

Wcale nie wspomniane zaniechania motywowały Timothy Snydera do napisania Skrwawionych ziem. „Wręcz przeciwnie - pisze Kühne - tym, co go złości, jest dominacja problematyki Holokaustu w północnoatlantyckiej polityce pamięci i historiografii”. Snyder uważa, że zamiast czerwca 1941 r., to wrzesień 1939 r. powinien stać się kluczowym punktem historii XX w., konkretnie zaś moment, w którym dwie totalitarne potęgi dokonały destrukcji Polski. Kühne przypomina, że podobny pomysł już kilka dekad wcześniej wysunąt Ernst Nolte, i że zabieg, który powtórzył za nim Snyder, jest co najmniej tak samo ryzykowny. Zadowoli on „prawicowe kręgi odbiorców”: niemieckich konserwatystów, pragnących „normalizacji” przeszłości, a także tych wschodnich Europejczyków i skrajnych nacjonalistów, którzy bagatelizują zbrodnie nazistów i uwypuklają zbrodnie komunistyczne, aby promować wspólną europejską pamięć, która zszywa ze sobą stalinizm i nazizm. Teoria podwójnego ludobójstwa jest zaiste wygodna: „dzięki niej wschodnioeuropejskie cierpienie skutecznie konkuruje z żydowskim, zaciera się różnica pomiędzy sprawcami i ofiarami, a wraz z nim gorzkie dziedzictwo współsprawstwa w Holokauście" [Zuroff 2010; Katz 2011].

Snyder może się z tym nie liczyć, jednak jego książka - sądzi Kühne - stanie się „biblią tych, którzy chcieliby wypaczyć przebieg Holokaustu w Europie wschodniej" [Zuroff 2012]. Jej wady można sprowadzić do dwóch skłonności autora: predylekcji do wielkich liczb i takich samych ludzi, a jednocześnie uderzającej niechęci do teorii. Stanowi to znaczący regres w badaniach nad historią masowych mordów. „Co to jest właściwie wiedza historyczna, czym jest teoria, co to znaczy rozumieć - na te wszystkie pytania książka Snydera nie daje odpowiedzi”. Gdybyśmy mieli je odgadywać w oparciu o tekst, moglibyśmy sądzić, że wiedza wynika „nie z analityki, ale statystyki” - z liczby ofiar poszczególnych reżimów. Przedmiotem licznych komplementów pod adresem książki jest specyficzna kombinacja liczb i świadectw. Kühne przypomina jednak, że to właśnie z powodu nadmiernego skupienia się na liczbach Snyder zdecydował się złagodzić świadectwami ich wymowę, wzywając następnie innych do "nadania liczbom ludzkiego wymiaru”.

Tym, co recenzenta rozczarowuje najbardziej, jest odwoływanie się przez Snydera do dewizy Leopolda von Ranke, dotyczącej ograniczenia się do tego, "co zdarzyło się naprawdę". Postulat jest bałamutny, co było wielokrotnie komentowane [Iggers 1973: XIX-XX]. „Historycy doskonale zdają sobie z tego sprawę - pisze Kühne - że ukazanie, co zdarzyło się naprawdę [bez pośrednictwa żadnej teorii], jest po prostu niemożliwe. Nie istnieje bowiem wiedza czysta, niezapośredniczona przez teorię. Są oczywiście rozmaite

4 Przekład tego tekstu opublikujemy w kolejnym numerze naszego pisma. 
odmiany tej ostatniej. Jedno z jej znaczeń odnosi się do naszych podstawowych, świadomych lub nie założeń odnośnie do tego, co każe ludziom działać, myśleć i odczuwać [...]. Istnieją też mniej lub bardziej świadome powody, dla których historycy zajmują się pewnymi tematami [...]. Do tej kategorii należą też poglądy dotyczące tego, co stanowi napęd historii i zmiany historycznej - wielkich idei, ludzi władzy, walki klas, konfliktów płci, chaosu przypadkowości albo też odwiecznej walki dobra i zła. Możemy bagatelizować, a nawet zaprzeczać faktowi, że teoria w omawianym znaczeniu kształtuje nasze badania i wpływa na to, co piszemy, ale w niczym nie zmniejszy to wpływu, jaki na nas wywiera". Szczególne zastosowanie ma to do historii porównawczej i scalającej, której przykładem są Skrwawione ziemie.

Kühne sądzi, że teza Snydera, który w rachunku ofiar wysuwa na plan pierwszy masowe egzekucje, jest co najmniej problematyczna. Traci bowiem z oczu kluczowy, jego zdaniem, „proces uczenia się, w którym naziści nie tylko poszukiwali najskuteczniejszego sposobu zabijania, ale także takiego, który wiązałby się z najmniejszym sprzeciwem sprawców i odbiorców w obrębie społeczeństwa”. To właśnie ów proces prób i błędów, poszukiwania równowagi pomiędzy skutecznością i wytrzymałością społeczną, uczynił Holokaust tym, czym byt.

Kühne wspomina dalej drugą (oprócz Hanny Arendt) tradycję porównywania totalitaryzmów, do której odwołuje się Snyder. Jest to Wasilija Grossmana Życie i los, dzieło literackie, w którym pisarz zestawia reżimy w „kategoriach uniwersalnych”, co pozwala ukazać „powszechną niegodziwość” systemu nazistowskiego i sowieckiego [Grossman 2009]. Zdaniem autora recenzji jest to jednak stanowczo za mało, aby uznać, że epoka masowych mordów uległa nadmiernej teoretyzacji. Także teoria ludobójstwa Rafała Lemkina, którą Snyder przywołuje w Skrwawionych ziemiach, jest użyta w sposób - jego zdaniem - niewłaściwy. Autor posługuje się nią bowiem bez odwołań do szczególnego przypadku masowych mordów, które miały na celu zagładę całego narodu. W dodatku Liczby i terminy kwituje go ledwie stwierdzeniem, iż „prowadził on do nieuchronnych i nierozstrzygalnych kontrowersji” [Snyder 2011: 446]. Tymczasem to właśnie dzięki niemu jesteśmy w stanie odróżnić Holokaust od masowych zbrodni stalinizmu. „Wymiaru cierpienia Ukraińców czy innych narodów wschodnioeuropejskich, jakich zaznały one od Hitlera czy Stalina, nie ma potrzeby umniejszać ani pod względem jakościowym, ani ilościowym. Wystarczy bowiem wskazać, że narody te ciągle istnieją, podczas gdy żydowska kultura Europy wschodniej zniknęła bez śladu".

Wbrew temu, co deklaruje autor, książka Snydera bazuje na znanej teorii „wielkich postaci”, uważa Kühne. Jej przedmiotem jest władza, jaką wybitne jednostki, nie zawsze dobre i moralne, są w stanie skupić w swoim ręku. Nadmiar władzy rządzących wymusza bierność rządzonych, w tym także bierność ofiar. W rezultacie „skrwawione ziemie” są przedstawione jako „boże igrzysko”"5, opowieść o starciu tytanów, w której wciąż po-

5 Tytuł książki Normana Davisa w recenzji nie pada, pojawia się natomiast rzeczownik playground. 
wracają indywidualistyczne, personalne formuły: „Stalin zwyciężył”, „Hitler wiedział”, „Stalin uszczelnił granice”, „Hitler nie okazał zainteresowania” etc. Niemiecka armia jest marionetką w ręku tego drugiego, tak jak Armia Czerwona w ręku pierwszego. To samo można powiedzieć o samym tzw. ostatecznym rozwiązaniu, przedstawionym w sposób zgodny z uproszczoną wizją intencjonalistów, bez wzmianki o rywalizacji pomiędzy różnymi ośrodkami dowodzenia, a także - bagatela - bez szerszej wzmianki o współudziale lokalnej ludności. „Tymczasem ani Stalin, ani Hitler samodzielnie nie zdołaliby przeforsować ani Wielkiej Trwogi, ani Holokaustu. Aby go przeprowadzić potrzebowali mnóstwo «zwyczajnych» wykonawców, a jeszcze bardziej ${ }^{6}$ potrzebowali «świadków». Aby zorganizować masowe mordy, musieli zintegrować w jedno ludzi różniących się co do chęci udziału w przedsięwzięciu, rozmaitych aktorów, współpracowników i pomocników, sadystów, fanatyków, zabójców z zimną krwią, tych, którym tylko czasem zdarzało się wątpić, i tych, którzy całkiem zwątpili, a także innych niechętnych, jednakże uległych". Wszyscy - całkowicie różni, a jednak współdziałający - ustanowili, zdaniem Kühnego, nowe, „mordercze społeczeństwo”.

Skupiając się na jednowymiarowym obrazie okrucieństwa zainicjowanego przez Hitlera i Stalina, Snyder pomija też kulturotwórcze cechy zbiorowej przemocy. Jak się okazuje, jest ona siłą produkującą społeczną dynamikę. Świadczą o tym studia Omera Bartova nad zagładą Żydów, która „posłużyła jako mechanizm mobilności społecznej - pozwoliła zająć lepsze domy po Żydach, przejąć ich interesy, obdarować strojami i biżuterią żony i kochanki, a dzieci zabawkami” [Bartov 2008]. Oprócz tego, że krzepi tożsamość, przemoc zbiorowa ustanawia też klasyczną więź społeczną, co udowodnili socjologowie zajmujący się włoską i amerykańską przestępczością zorganizowaną. „Są dwa sposoby, aby zjednoczyć ludzi: wspólne ideały i wspólnie popełniona zbrodnia" - od tego zdania, wypowiedzianego przez Adolfa Hitlera w Monachium w 1923 r. zaczyna się książka Thomasa Kühnego [Kühn: 2010]. Podobne obserwacje mieli też badacze ludobójstwa rwandyjskiego. „Zabijanie Tutsich - zauważył Philip Gourevitch - bardzo zbliżyło ludzi do siebie" [Gourevitch 1998]. Ludobójcze reżimy czerpią siłę nie tylko z obsesji na punkcie czystości i z lęku przed splamieniem. Odpowiadając na społeczne obawy o tożsamość zbiorową i narodową spójność, dokonują one restytucji i „naprawy” tożsamości, zwalczając ambiwalencję i pomieszanie. Jak dowodził Saul Friedländer, niemiecki „odkupicielski antysemityzm" odegrał rolę zbawienia przez eksterminację [Friedländer 1997-2007], dostarczając Niemcom niepowtarzalnych stanów społecznej harmonii i spójności Volksgemeinschaft [Kühne 2010].

6 Ang. more można w tym przypadku rozumieć zarówno jako „więcej”, jak i „bardziej”. W tym drugim przypadku być może Kühnemu chodzi o zasadę znaną z psychologii społecznej, że bierność świadków stanowi zachętę do przestępstwa. Por. Zerubavel 2006. 
Czwarty z autorów przeglądu, Jörg Baberowski, znajduje się w najtrudniejszej sytuacji, bowiem - ze wzgledu na kolejność - jego argumenty brzmią, jak powtarzane po kolegach. Z wyjątkiem jednego - w którym podkreśla zmienność standardów w badaniach historycznych w ciągu ostatnich dekad. Dwadzieścia lat temu - pisze - zestawianie zbrodni nazizmu z okrucieństwami bolszewizmu byłoby nie do pomyślenia. Nazywano by to relatywizacją historii i byłoby to określenie słuszne, bowiem zestawienia zawsze rzucają nowe światło na zjawisko, prowadząc do powstania nowej perspektywy, zrelatywizowanej wobec punktu odniesienia. „Były to jednak czasy, gdy wszystkie zjawiska historyczne traktowano w kategoriach moralnych [...]. Można też było porównywać wszystko ze wszystkim z wyjątkiem Holokaustu". Ktoś, kto zdecydował się pisać o okrucieństwach stalinizmu, musiał dodać na końcu rytualną formułę, że nazizm i tak był najgorszy.

Jeden z wniosków ze sporu historyków wydaje się Baberowskiemu niepodważalny: aby ustalić, że coś jest unikalne, musi zostać wszechstronnie prześwietlone pod względem porównawczym. „Wniosek, który najpierw wydawał się szokujący, stał się po prostu oczywisty: żadnych okrucieństw popełnianych w imieniu państwa nie bada się [dziś] inaczej, jak właśnie przez ich porównywanie. Zmiana powyższa może też jednak służyć celom politycznym: Holokaust stał się kryterium, za pomocą którego mierzy się państwowe zbrodnie i tylko wtedy traktuje się je serio, jeśli są porównywalne z nazistowskimi” ostrzega Baberowski.

\section{V}

Streszczenie bardzo obszernej odpowiedzi Snydera jest praktycznie niemożliwe - nazbyt wikłałoby się w powtórzenia. Ograniczę się więc do wyboru kilku elementów, które chciałabym połączyć z tym, co miałam okazję sama usłyszeć w czasie wykładu autora w Princeton w lutym 2012 r. On właśnie posłużył Snyderowi za postawę odpowiedzi krytykom, opublikowanej w „Contemporary European History”.

Komentarz do czterech omówionych recenzji autor Skrwawionych ziem rozpoczyna od przywołania Naszej klasy Tadeusza Słobodzianka7, którą w ubiegłym roku z wielkim powodzeniem wystawiano w Filadelfii. Nazywa ją „reinterpretacją pionierskiej książki Jana Grossa", co stanowi nieścisłość, gdyż sztuka Słobodzianka jest raczej trawestacją pracy My z Jedwabnego Anny Bikont (2004 r.). Przywołanie nazwiska Grossa ma jednak zupełnie inny, symboliczny cel. Jest tarczą przeciwko krytykom, którzy jak jeden mąż wypominają autorowi pominięcie Jedwabnego. Ponieważ wizje przedstawione w mikrohistorii Sąsiadów i mezohistorii Snydera dzieli wszystko, przywołującemu chodzi zapewne o zniwelowanie złego wrażenia.

7 Nazwisko Słobodzianka Snyder podaje z błędną końcówką. 
Snyder wyraża zawód, że jego recenzenci uparcie powracają do opisów, do których są przyzwyczajeni. Winę za to przypisuje - aluzyjnie, ale wyraźnie - powszechnej na Zachodzie nieznajomości języków wschodnioeuropejskich. Nie wydaje się to sprawiedliwe (zważywszy słabą znajomość języków zachodnich na Wschodzie), ani wielkoduszne, bo choć znajomością dwunastu (!) języków Snyder prawdopodobnie bije na głowę recenzentów, to jednak żaden z nich tego ataku nie sprowokował: nikt nie zakwestionował zasadności przesunięcia „teatru historii” na Wschód. Ponadto gdyby to sama znajomość języków miała decydować, kto jest najlepszym historykiem, wygraliby językoznawcy.

Proponowany poziom analizy Snyder określa mianem „mezo-”, czyli czegoś pomiędzy „makro-” i „mikro-”. Wyznacza je terytorium „skrwawionych ziem”. Stają się one regionalną transnational unit, zgodną z duchem czasu, bo ze „zwrotem terytorialnym”, jaki obserwujemy w naukach historycznych. Wybierając podobną jednostkę i wynikający z niej poziom analizy, można dostrzec więcej, niż pozwala na to inna, najpowszechniejsza dotąd optyka „mezo-”, czyli perspektywa narodowa. Tę ostatnią Snyder krytykuje jako obciążoną dwojakim błędem: biographical and genealogical fallacy. Sprowadza się on do przekleństwa narracji dominującej, która rozpoznaje zasadnicze pytania, jakie zadaje sobie grupa: „Dlaczego byliśmy ofiarami?”, „Dlaczego byliśmy sprawcami?”, „Dlaczego przypatrywaliśmy się temu wszystkiemu biernie?" - ale nie potrafi na nie odpowiedzieć.

„Historia narodowa - pisze Snyder w odpowiedzi krytykom - ma potężny wpływ na wyobraźnię i strategie obronne, z których wiele ujawnia się w powyższych recenzjach. Niewielu historyków powiedziałoby otwarcie, że historia, w której się specjalizują, jest szczególna, ponieważ ich naród jest wyjątkowy. Wielu z nich zaś, w konfrontacji z ograniczeniami historii narodowej, będzie bronić narodu, uciekając się do moralizowania lub teorii. Ponieważ na Zachodzie nie ma zwyczaju deklarować, że naród, z którego pochodzimy, jest wyjątkowy, będą oni twierdzić, że to właśnie szczególne doświadczenie narodowe daje dostęp do zasadniczych kwestii moralnych czy teoretycznych". To oczywista aluzja do Dana Dinera i jego przekonania o wyjątkowości historii żydowskiej, a także do Thomasa Kühnego, przywiązanego - w opinii Snydera - do niemieckiej Sonderweg i dlatego uciekającego się do "moralizowania i teoretyzowania”. O ile w odniesieniu do pierwszego z dyskutantów zarzut mógłby być w jakimś stopniu uzasadniony (uprzywilejowanie Holokaustu sugerowało rozmaite inne uprzywilejowania), w stosunku do drugiego jest zupełnie chybiony. Każdy, kto zapoznał się z debatami teoretycznymi XX w., wie, że postulat ujawniania teorii nie jest wekslowaniem rozmowy o przeszłości na inne tory, ale przeciwnie, dbałością o to, by dotyczyła ona dokładnie tego przedmiotu, który obie strony mają na myśli. Sugerowanie, tym bardziej z powołaniem się na Rankego, że najpierw należy zrekonstruować „to, co wydarzyło się naprawdę”, a dopiero potem zastosować teorię, jest, by posłużyć się bon motem Oskara Miłosza w sprawie kolejności modlitwy i wiary, „stawianiem wozu przed koniem”. Dictum Snydera, dopuszczającego tym samym możliwość poznania bezpośredniego, stanowi zdumiewający i niebezpieczny 
regres, cofający nas do lat sześćdziesiątych XX w. ${ }^{8}$, a zważywszy, co na temat uwikłania historyka pisał przed wojną Marceli Handelsman [Handelsman 1928] - nawet trzy dekady wcześniej. Pytany w czasie wykładu princetońskiego, dlaczego nie omawia w swojej książce teoretycznego zaplecza porównań, doboru przykładów, itp., Snyder tłumaczył ich brak następująco: „criteria do not often need to be publicly enunciated; we appeal to criteria only when the sense of mutual attunement is threatened" ('Kryteriów nie trzeba omawiać publicznie; odwołujemy się do kryteriów tylko wtedy, gdy zagrożone jest poczucie powszechnej zgody'). Czy recepcja jego książki nie dowodzi, że mamy do czynienia z taką właśnie sytuacją?

Zagadnienie to jest ściśle związane z kategorią ideologii, której Snyder sam używa w znaczeniu wysoce zideologizowanym, bo służącym do piętnowania totalitarnych reżimów (w wykładzie princetońskim zarysował sprzężenia pomiędzy ideologią, motywem i okrucieństwem w nazizmie i stalinizmie). Przypomnijmy zatem opinię wcale niemarksisty, tylko Karla Mannheima z Ideologii i utopii, iż to, co dla jednego jest nauką, dla innego będzie ideologią. W aspirującym do obiektywnego badaniu historycznym wskazane byłoby posługiwanie się takim znaczeniem tego słowa, które pozwoliłoby na objęcie nim nie tylko naszych przeciwników, ale i nas samych?.

Także riposta Snydera na dalszą część krytyki ze strony Kühnego pozostawia wiele do życzenia. Ostatnią rzeczą, jaką można zarzucić niemieckiemu historykowi, jest German exceptionalism, którego łatkę usiłuje mu przypiąć. Gdyby przed wydaniem Skrwawionych ziem Snyder zdążył zapoznać się z jego książką Belonging and Genocide: Hitler’s Community, 1918-1945, zrozumiałby, jak inkluzywną perspektywą operuje jego adwersarz. Praca stanowi przykład znakomitego interdyscyplinarnego połączenia warsztatów nauk historycznych, dzięki któremu przeszłość ukazuje się jako sieć relacji socjo-pedagogicznych (chciało by się dodać: w znaczeniu Foucaultiańskiego apparatus-dispositif), a wnioski dotyczące sposobu, w jaki pod wpływem legalnego zabijania społeczeństwo niemieckie przekształciło się w „społeczeństwo mordercze”, można z pożytkiem rozszerzyć na inne populacje na wschód od Auschwitz. Tym, co wówczas moglibyśmy uzyskać, byłby obraz grup, które składały się nie tylko ze sprawców, ofiar i świadków, ale z całego legionu aktorów. Aby skutecznie przeprowadzić masowe mordy, nie wystarczało bowiem - powtórzmy to za Kühnem - „ułożyć” ludzi w samych Niemczech. Trzeba było to przeprowadzić także na „krwawiących ziemiach”. Pracę nad podobnym zagadnieniem rozpoczął Jan Tomasz Gross, wysuwając tezę, że „antysemityzm rozpowszechniony w czasie okupacji wśród polskiego społeczeństwa był przyczyną, dla której Niemcy tak brutalnie i bezwyjątkowo bezwzględnie mordowali Polaków za pomaganie Żydom" [Gross 1986: 24]. Skoro - jak wiemy z dawnych i najnowszych badań - nie tylko w Niemczech istniało przyzwolenie na zabijanie Żydów, stosowalność tezy Kühnego trudno ograniczyć

8 W kategoriach historii filozofii zagadnienie wyłożone jest w drugiej części Prawdy i metody Hansa Georga Gadamera, pt. Rozszerzenie kwestii prawdy na rozumienie w naukach humanistycznych [Gadamer 1993].

9 Jeśli chodzi o ujęcia lewicowe, to takim znaczeniem pojęcia ideologia posługuje się na przykład Louis Althusser [Grant 2005]. Jeśli chodzi o ujęcia konserwatywne, można by wybierać pomiędzy Michaelem Polanyim [Polanyi 1967] czy Mary Douglas [Douglas 2007]. 
do terenu na wschód od Auschwitz. Powodzenie Holokaustu, powtórzmy raz jeszcze za recenzentem, zależało od całej rzeszy udziałowców, „różniących się co do chęci udziału w przedsięwzięciu, rozmaitych aktorów, współpracowników i pomocników, sadystów, fanatyków, zabójców z zimną krwią, tych, którym tylko czasem zdarzało się wątpić, i tych, którzy całkiem zwątpili, a także innych niechętnych, jednakże uległych". Wszyscy oni, różni, a jednak pod wieloma względami współdziałający, stanowili także społeczeństwo „krwawiących ziem”, którego zbadanie jest wciąż przed nami.

Przy realizacji podobnego zadania zniuansowana koncentracja na sprawcach i świadkach ma znacznie więcej szans powodzenia niż homogenizacja ofiar dwóch reżimów (a zarazem samych reżimów). Timothy Snyder, który zdecydował się na to drugie, czyli homogenizację, zachowuje się jak podmiot straumatyzowany odkryciem rozmiarów zbrodni, który - za Rubinsztajnem z warszawskiego getta - powtarza okrzyk alle gleich! ${ }^{10}$. Problem w tym, że poza gettem okrzyk ten ma zupełnie inne znaczenie.

Z punktu widzenia etnografa Skrwawione ziemie są książką szczególną. Każdy, kto prowadził badania terenowe w Europie Środkowo-Wschodniej na temat pamięci drugiej wojny światowej, wie, że „krwawiąca ziemia” jest charakterystycznym ludowym toposem, którego występowanie zupełnie obiektywnie wyznacza - czy raczej wyznaczało w czasach, gdy nikt się tym jeszcze nie interesował - zasięg „skrwawionych ziem”11. Można więc powiedzieć, że sam teren weryfikuje tezy historyka. Nasuwa się jednak pytanie, czy historyk odwzajemnia się tym samym. Na podstawie wschodnioeuropejskich reakcji na książkę można bowiem odnieść wrażenie, że badacz stworzył dzieło na zamówienie „terenu", co w etnografii nazywa się elegancko go native ${ }^{12}$.

Największą zasługą Snydera jest dokonanie wyłomu w uroczystej ciszy, jaka otaczała Holokaust na Zachodzie, już po tym, jak temat został konkluzywnie opisany, a także w tych krajach Europy Wschodniej, gdzie bynajmniej opisany nie został. Co tę ciszę zastąpi? Czy pogłębiona refleksja nad tematem, czy westchnienie ulgi, że pogłębiać go już nie trzeba?

W ripoście Snydera pojawia się zdanie: „history is not about comfort”. Chciałoby się je powtórzyć, i to z wykrzyknikiem, gdy czyta się głosy i polskie ${ }^{13}$, i te dobiegające zza granicy. Takie jak głos premiera Litwy, Andriusa Kubiliusa: „co do pogromu w Kownie i w ogóle likwidacji litewskich Żydów w czasie drugiej wojny światowej, to nie mam

10 „Rubisztajn - wariat uliczny, jako jedyny w getcie nie uciekał przed Niemcami. Podbiegał do nich i krzyczał: alle gleich! - co oznaczało, że w getcie wszyscy ludzie są równi i skazani na ten sam los”, cyt. za:www.getto.pl/index.php? mod=view_record\&rid=5104463245632247874\&tid=zdarzenia. Zob. też Grynberg, Kostański 2001.

11 Obraz ziemi broczącej krwią powraca w książce Anny Engelking, Kołchoźnicy. Antropologiczne studium tożsamości wsi białoruskiej przełomu XX i XXI wieku w rozdziale 7: Chłopi i żydzi. Między strukturą a communitas, w podrozdziale: Pamięć Zagłady po raz drugi, czyli pytanie o porządek świata.

12 Zob. fragmenty wywiadu, udzielonego dziennikarce telewizyjnej, Kamili Dreckiej: „Snyder: Do dzisiejszego dnia język polski jest naszą [tzn. Snydera i jego żony, Marcii Shore] Geheim Sprache. To jest język, który używamy, kiedy nie chcemy być przez świat zrozumiani. Drecka: I czytacie dziecku Lokomotywe Tuwima ? Snyder: Oczywiście, ja nie jestem w stanie cytować całej tej poezji, ale czytam oczywiście Lokomotywę prawie każdego dnia, czytam na głos" [Snyder 2012b].

13 W czerwcu 2012 w konsulacie RP w Nowym Jorku Timothy Snydera uhonorowano medalem imienia Józefa Piłsudskiego. 
problemu z tym, by przyznać, że to wielka tragedia, zwłaszcza, że brali w tym udział Litwini. Niedawno poleciłem przetłumaczyć i wydać po litewsku książkę Timothy Snydera Skrwawione ziemie, w której autor opisuje, co się wtedy działo w naszej części Europy i jaki wpływ na nas miały oba totalitaryzmy: hitlerowski i stalinowski. Pomoże nam ona lepiej zrozumieć swoją winę, ale w obiektywnym świetle. Mam nadzieję, że dyskusja o litewskim udziale w Holokauście jest już poza nami”14. Jakiś błąd musi tkwić w tej książce, jeśli wydaje się zamykać dyskusję, która się nawet nie rozpoczęła.

\section{Bibliografia:}

Bartov Omer, 2008, Eastern Europe as the Site of Genocide, „Journal of Modern History” 80, s. 557-593.

Bartov Omer, 2011, [rec. z Timothy Snyder, Bloodlands], „Zagłada Żydów. Studia i Materiały” 7, s. 595-600.

Bullock Alan, 1993, Hitler and Stalin, New York: Vintage Books.

Chodakiewicz Marek Jan, 2004, Between Nazis and Soviets: Occupation Politics in Poland, 1939-1947, Lanham, Md.: Lexington Books.

Douglas Mary, 2007, Ukryte znaczenia, tłum. Ewa Klekot, Kęty: Wydawnictwo Marek Derewiecki.

Engelking Anna, 2012, Kołchoźnicy, Antropologiczne studium tożsamości wsi białoruskiej przełomu XX i XXI wieku, Toruń [Monografie Fundacji na Rzecz Nauki Polskiej].

Friedländer Saul, 1997-2007, Nazi Germany and the Jews, t. 1-2, London: Widenfeld \& Nicolson.

Gadamer Hans Georg, 1993, Prawda i metoda. Zarys hermeneutyki filozoficznej, przeł. Bogdan Baran, Kraków: Inter Esse.

Gourevitch Phillip, 1998, We Wish to Inform You That Tomorrow We Will Be Killed with Our Families: Stories From Rwanda, New York: Farrar, Straus and Giroux.

Grant John, 2005, Rethinking Althusser: Ideology, Dialectics, and Critical Social Theory; www.cpsa-acsp.ca/ papers-2005/Grant.pdf (dostęp z 22 sierpnia 2012).

Gross Jan Tomasz, 1986, Ten jest z ojczyzny mojej, ale go nie lubię, „Aneks”, nr 41-42.

Gross Jan Tomasz, 1988, Revolution from Abroad. The Soviet Conquest of Poland's Western Ukraine and Western Belorussia, Princeton: Princeton University Press.

Grossman Wasilij, 2009, Życie i myśl, tłum. Jerzy Czech, wstęp Andrzej Pomorski, Warszawa: W.A.B.

Grynberg Henryk, Kostański Jan, 2001, Szmuglerzy, Warszawa: Twój Styl.

Handelsman Marceli, 1928, Historyka. Zasady metodologji i teorji poznania, wyd. 2: Warszawa: Gebethner i Wolff.

Historikerstreit 1987 - Historikerstreit. Die Dokumentation der Kontroverse über Einzigartigkeit der nationalsozialistichen Judenvernichtung, München: Piper.

Holzer Jerzy, Kuisz Jarosław, Jasina Łukasz, Kenney Padraic, 2011, Skrwawiony Wschód, naiwny Zachód, „Kultura Liberalna" z 20 maja 2010; kulturaliberalna.pl/2011/05/20/holzer-kuisz-jasina-kenney-skrwawionywschod-naiwny-zachod (dostęp z 22 sierpnia 2012).

14 Jest to odpowiedź na - powtórzone za Tomasem Venclovą - pytanie Adama Michnika, dlaczego w żadnym litewskim podręczniku historii nie ma mowy o pogromie Żydów w Kownie przez paramilitarne jednostki litewskie [Kubilius 2012]. 
Iggers Georg, 1973, [wstęp], w: Leopold Ranke, The Theory and Practice of History, wyd. Georg G.Iggers, tłum. Wilma Iggers, Konrad von Moltke, Indianapolis: Bobbs-Merrill.

Kailitz Steffen (red.), 2008, Die Gegenwart der Vergangenheit. Der „Historikerstreit“ und die deutsche Geschichtspolitik, Wiesbaden: VS Verlag für Sozialwissenschaften.

Kalicki Włodzimierz, 2011, Wielkie zabijanie, „Gazeta Wyborcza” z 31 maja 2011; wyborcza.pl/ 1,75475,9696306,Wielkie_zabijanie.html (dostęp z 22 sierpnia 2012).

Katz Dovid, 2011, Why Red is not Brown in the Baltics, „The Guardian” z 30 września 2011; www.guardian.co.uk/commentisfree/cifamerica/2010/sep/30/baltic-nazi-soviet-snyder?INTCMP=SRCH (dostęp z 22 sierpnia 2012).

Kubilius Andrius, 2012, Piłsudski, dobroczyńca Litwy. Rozmawiali Adam Michnik i Marcin Wojciechowski, „Gazeta Wyborcza. Magazyn" z dnia 5 maja 2012, s. 27.

Kühne Thomas, 2010, Belonging and Genocide: Hitler's Community, 1918-1945, New Haven: Yale University Press.

Leszczyński A., 2010, Historyk patrzy na rzeźnię, „Gazeta Wyborcza” z 4-5 grudnia 2010; wyborcza.pl/1,76842,8763648,Historyk_patrzy_na_rzeznie.html (dostęp z 22 sierpnia 2012).

Overy Richard, 2004, The Dictators: Hitler's Germany and Stalin's Russia, London: Allen Lane.

Polanyi Michael, 1967, The Tacit Dimension, New York: Anchor Books.

Sienkiewicz Bartłomiej, 2011, Niema Polska, „Tygodnik Powszechny”, nr 27 z 3 lipca 2011; tygodnik.onet.pl/ 35,0,65178,niema_polska,artykul.html (dostęp z 22 sierpnia 2012).

Skrwawiony teatr, 2011 - Skrwawiony teatr ponadnarodowej historii. Debata redakcyjna z Timothy Snyderem, „Kultura Liberalna” z 16 sierpnia 2011; kulturaliberalna.pl/2011/08/16/skrwawiony-teatr-ponadnarodowej -historii-debata-redakcyjna-z-timothym-snyderem/ oraz www.rp.pl/artykul/705028.html - (dostęp z 22 sierpnia 2012).

Snyder Timothy, 2010, Bloodlands. Europe between Hitler and Stalin, New York: Basic Books.

Snyder Timothy, 2011, Skrwawione ziemie. Europa między Hitlerem a Stalinem, tłum. Bartłomiej Pietrzyk, Warszawa: Świat Książki.

Snyder Timothy, 2012a, Skrwawione ziemie Europy, „Uważam Rze” z 8 kwietnia 1012; www.uwazamrze.pl/ artykul/856409.html (dostęp z 22 sierpnia 2012).

Snyder Timothy, 2012b, Zrównuję ludzkie losy, ale nie zbrodnie. Wywiad Kamili Dreckiej z Timothy Snyderem, „tvp.info” z 19 maja 2012; tvp.info/opinie/wywiady/zrownuje-ludzkie-losy-ale-nie-zbrodnie/7394225 (dostęp z 22 sierpnia 2012).

Zerubavel Eviatar, 2006, Elephant in the Room. Silence and Denial in Everyday Life, Oxford-New York: Oxford University Press.

Zuroff Efraim, 2010, A Dangerous Nazi-Soviet Equivalence, „The Guardian” z 29 września 2010; www.guardian.co.uk/commentisfree/cifamerica/2010/sep/29/secondworldwar-holocaust?INTCMP=SRCH (dostęp z 22 sierpnia 2012).

Zuroff Efraim, 2012, Fałszywy znak równości, „Studia Litteraria et Historica” 1; www.ispan.waw.pl/SLH/ content/fałszywy-znak-równości.

Żbikowski Andrzej, 2011, [rec. z Timothy Snyder, Skrwawione ziemie], „Zagłada Żydów. Studia i Materiały” 7 , s. 583-594. 